\section{Aspects of the quality of accounting in the international context}

\section{Sady Mazzioni}

Universidade Comunitária da Região de Chapecó, Postgraduate Accounting and Business Administration Program, Chapecó, Brazil

\section{Roberto Carlos Klann}

Universidade Regional de Blumenau, Postgraduate Program in Accounting, Blumenau, Brazil
Received on

08/28/2016

Approved on

$08 / 13 / 2017$

Responsible editor:

Prof. Dr. Ivam Ricardo Peleias

Evaluation process:

Double Blind Review

\begin{abstract}
Purpose - Analyze how the characteristics of the business environment generates differences in the quality of accounting information in the international context.

Design/methodology/approach - Descriptive research with a quantitative approach. Documentation collection in the Thomson Datastream Index Service database in a sample of 1,406 companies located in twelve countries, from 2005 to 2012.
\end{abstract}

Findings - Companies located in countries with lower tax burden, stronger legal environment, greater economic and financial development index, common law legal origin and higher degree of internationalization presented higher averages and significant differences in the aggregate ranking of the quality of accounting information. The type of standard accounting used also influenced the position in the aggregate ranking of the accounting information quality.

Originality/value - The interaction of companies with external markets influences the choices of accounting policies. The countries' environmental characteristics, related to transparency, economic nature, legal and tax environment, lead to various levels of the quality of accounting information reported by companies.

Keywords - Quality of accruals. Persistence. Predictability. Smoothness.

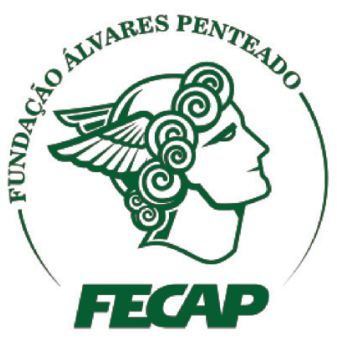

Review of Business Management 


\section{Introduction}

The "earnings quality" or, more generally, financial reporting quality does not have a precise definition. In the literature, financial reporting quality is generally defined as the extent to which reported earnings in financial statements faithfully represent underlying economic constructs and the degree to which reported earnings reflect basic accounting concepts (Yoon, 2007; Chen, Tang, Jiang, \& Lin, 2010).

Generally Accepted Accounting Principles have come under increased criticism as a contributing factor in several recent accounting and business failures. Critics argue that the standards are complex and difficult to apply. The result is an increasing number of restatements in recent years. Others claim that the Generally Accepted Accounting Principles is overly "rulebased" and therefore contributes to transactionstructuring to get desired reporting results (Kohlbeck \& Warfield, 2010).

The quality of accounting information is influenced by several regulatory factors, such as: high quality accounting standards, especially the adoption of IFRS (Barth, Landsman, \& Lang, 2008; Iatridis, 2010; Houqe, Van Zijl, Dunstan, \& Karim, 2012); the origin of the country's legal system (La Porta, Lopez-De-Silanes, Shleifer, \& Vishny, 1998; Soderstrom \& Sun, 2007; La Porta, Lopez-De-Silanes, \& Shleifer, 2008); the existence of laws to protect the securities market and their effective application (Houqe et al., 2012); the legal protection of the interests of minority shareholders (La Porta et al., 1998; Houqe et al., 2012); effective application of accounting and auditing standards (Houqe et al., 2012); efficiency and integrity of the legal environment over business (La Porta et al.; 1998; Houqe et al. 2012); and the influence of the tax system in the intensity of the alignment between accounting profit and taxable income (Soderstrom \& Sun, 2007; Houqe et al., 2012).

Although empirical evidences have demonstrated that high quality patterns (such as the IFRS) generally improve the accounting quality (Barth et al., 2008; Daske, Hail, Leuz, \& Verdi, 2008), other evidences suggest that the accounting standards have a limited role in determining the quality of accounting reports (Burgstahler, Hail, \& Leuz, 2006).

The accounting standards generally provide substantial flexibility for the companies. The measurements are often based on private information and the application of accounting standards involves judgment. Corporate managers may use discretionary power in the reports to convey information about the firm's economic performance, but they may also make improper use of the criteria when it is in their interest. Consequently, the business incentives are likely to play a fundamental role in the determination of the informativeness of the earnings reported (Burgstahler et al., 2006).

The firms are motivated by certain incentives in the promotion of accounting numbers that influence the quality of reports, such as: the concentration of ownership (Barth et al., 2008; Gaio, 2010; Chen et al.; 2010; Isidro \& Raonic, 2012); the presence of financial leverage (Barth et al., 2008; Kohlbeck \& Warfield, 2010); the presence in foreign listings (Barth et al., 2008; Isidro \& Raonic, 2012); their economic performance (Burgstahler et al., 2006; Iatridis, 2010); the level of the country's economic development (Burgstahler et al., 2006; Gaio, 2010; Isidro \& Raonic, 2012); the level of financial development of the country (Gaio, 2010; Isidro \& Raonic, 2012), and the level of combating corruption (La Porta et al., 1998), among other impelling incentives.

The firms that have diversified operations abroad have greater incentives to provide extensive financial information to their foreign clients, suppliers and potential investors (Isidro $\&$ Raonic, 2012). Besides that, the international capital competition generated incentives that improved the quality and the accounting comparability (Land \& Lang, 2002). In addition, institutional and foreign investors prefer high 
quality financial information when making international investments (Bradshaw, Bushee, \& Miller, 2004).

Based on this context, this study intends to answer the following research problem: how does the characteristics of the business environment incite differences in the quality of accounting information in the international context? The objective of this study is to analyze how the characteristics of the business environment incites differences in the quality of accounting information in the international context.

The justification of this study is related to the results' practical contribution, which are of interest to professionals such as accountants, consultants, market analysts, auditors, professionals responsible for the elaboration of accounting standards and researchers. For the firms, the results are important due to the possibility of evaluating how the interaction with the international market influences in the choices of accounting policies, reinforcing the principle that high quality accounting information can reduce agency problems caused by information asymmetry between firms and investors (Ball, Kothari, \& Robin, 2000).

This study presents empirical evidences that environmental characteristics of different countries related to transparency, economic nature, legal and tax environment can lead to differentiated levels in the quality of accounting information reported by companies.

\section{Literature review}

It is hard to observe the quality of accounting information, and, consequently, it is also difficult to be measured (Isidro \& Raonic, 2012). There is no general agreement nor a predominant approach to measure the quality of the accounting results due to the attributes that can be mutually incompatible or overlapping, interconnected, and cannot be considered separately (Yoon, 2007).

Although there is no agreement regarding the quality of accounting information definition, the different dimensions that form its construct were operationalized in previous researches. The studies generally develop quality measures based on the use of disclosed profits and profit components, defining the construct as "quality of profits" or "quality of accruals" (Hribar, Kravet, \& Wilson, 2014).

The definitions of the quality of profits include the high persistence of profit in a time series; profits that represent accurately the economic implications of underlying operations; the ratio of earnings in relation to operating cash flows; accruals of working capital mapped in past, present and future cash flows (McNichols, 2002).

This study considers the quality of accounting information based on the individual ranking by company, which is composed by four attributes of profits based on the accounting: quality of accruals, persistence, predictability and smoothing of earnings.

\section{I Quality of accruals}

The accruals, or accounting accumulations by competence regime, may be understood as the difference between net profit and net operating cash flows, that is, the accruals are constituted by integral values in the income statements that were included in the profit statement but do not imply the necessary movement of financial resources (Martinez, 2008).

Accruals reflect reporting choices and cash flows reflect fundamental economic gains and losses. The accruals and the quality profit are related, and the transitory change in the operating cash flow occur due to manipulation management triggered by the variation of working capital items over time, leading to lower quality gains (Ball \& Shivakumar, 2005).

Although a negative correlation with the cash flow is considered a "natural" result of accruals accounting (Dechow, 1994), greater magnitudes of this correlation can indicate a smoothing of reported earnings that do not reflect the companies' economic performance (Myers, Myers, \& Skinner, 2006). 
The existence of extreme accruals is considered as low quality, as they represent a less persistent component of the results (Dechow, Ge, \& Schrand, 2010). The accruals are related to revenue and expenses that are recognized based on the competence regime, and not as result of the effective receiving of cash receipts revenue or of the actual payment of the expense (Goulart, 2007).

Accruals are classified as nondiscretionary and discretionary (Martinez, 2001). The nondiscretionary accruals derive from the reality of the business, whereas discretionary accruals would be artificial, with the sole purpose of "managing" the accounting result (Martinez, 2001).

The regulatory and accounting patterns flexibility allow managers to practice discretion in the choice of accounting criteria and procedures that will be adopted (Goulart, 2007). Based on the possibility of accounting choices, there are several attempts to separate the discretionary accruals from the nondiscretionary accruals.

Models vary from the simplest, in which total accruals are used as a measure of discretionary accruals, to those relatively sophisticated, which decompose the additions into discretionary and nondiscretionary components with the use of regression.

In the Dechow and Dichev (2002) approach, presented in Figure 1 and used in this study, accruals are modeled as a function of past, present and future cash flows, due to its purpose of modifying the recognition time of the cash flow in the profits.

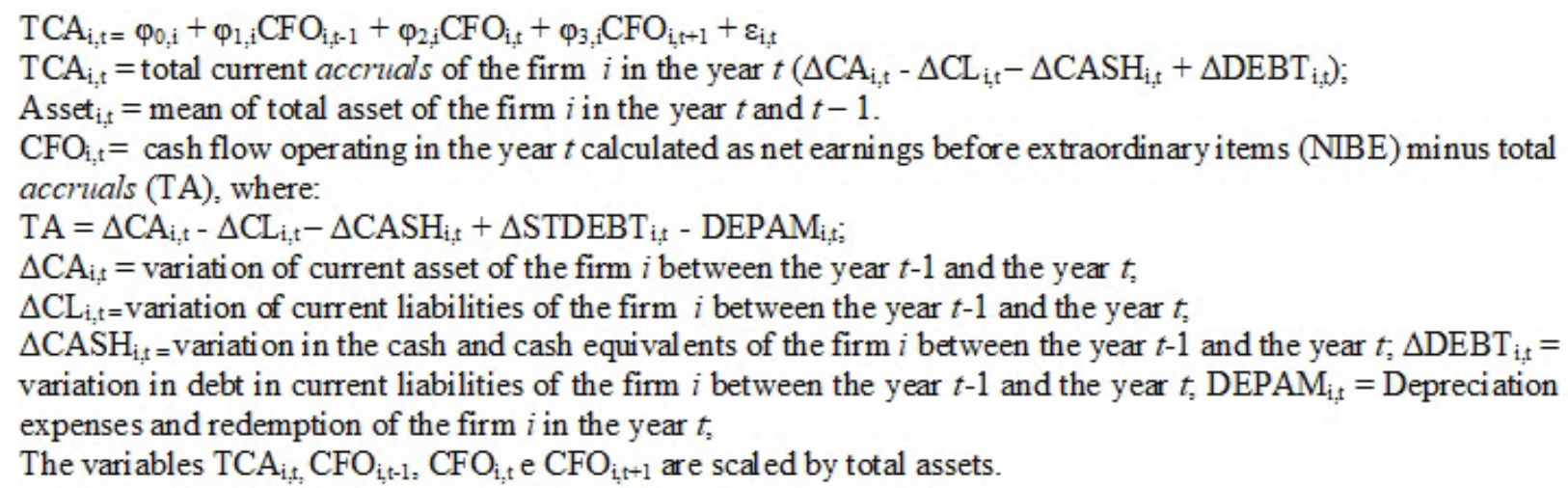

Figure 1 - Model to measure current accruals

Source: Adapted from "The quality of accruals and earnings: The role of accrual estimation errors", by P. Dechow and I. Dichey, 2002, The Accounting Review, 77, 35-59.

The accruals' quality measure is equal to the standard deviation of the residues of the equation presented in Figure 1, the higher values indicating lower quality accruals, and thus, low quality profit (Francis, Lafond, Olsson, \& Schipper, 2004; Gaio, 2010). Accruals represent a key role in the study regarding the quality of accounting information. The quality of accruals is related to more persistent profits and to the improvement in the ability of earnings in evaluating the company's performance.

\subsection{Persistence of earnings}

In the evaluation of Dechow, Ge, and Schran (2010), one of the main lines of research on persistent earnings is the one motivated by an assumption that more persistent earnings will yield better inputs to equity valuation models and, hence, more persistent earnings are regarded as being of higher quality than less persistent earnings.

Current earnings must be a good indicator of future earnings; its quality can be understood 
as the probability that a firm may have persistent current earnings in the future (Penman \& Zhang, 2002). Firms with more persistent earnings have a more "sustainable" earnings/cash flow stream that will make it a more useful factor for the equity valuation based on the discounted cash flows (Dechow et al., 2010).
According to Kohlbeck and Warfield (2010), profit persistence seizes permanence of earnings from one period to the next and is estimated by the regression of earnings of the current period in the income of the previous period. Figure 2 presents the model used in this study for measuring the persistence of profits.

$$
\mathrm{X}_{\mathrm{i}, \mathrm{t}}=\Phi_{\mathrm{o}, \mathrm{i}}+\Phi_{1, \mathrm{i}} \mathrm{x}_{\mathrm{i}, \mathrm{t}-\mathrm{1}}+\mathrm{v}_{\mathrm{i}, \mathrm{t}}
$$

$\mathrm{X}_{\mathrm{i}, \mathrm{t}}=$ net income before extraordinary items of the firm $i$ in the year $t$ divided by weighted mean number of shares in use during the year $t$.

$\mathrm{X}_{\mathrm{i},-1}=$ net income before extraordinary items of the firm $i$ in the year $t$ divided by weighted mean number of shares in use during the year $t-1$.

Figure 2 - Model to measure persistent earnings

Source: Adapted from "Costs of equity and earnings attributes", by J. Francis, R. Lafond, P. M. Olsson and K. Schipper, 2004, The Accounting Review, 79, 967-1010.

The model of Francis et al. (2004), also used also by Yoon (2007) and Gaio (2010), is presented in Figure 2. This model generates specific year and firm estimates $\left(\Phi_{1, \mathrm{i}}\right.$, that sum up the persistence of gains. Values of $\Phi_{1, \mathrm{i}}$ close to 1 imply in highly persistent earnings, whereas values of $\Phi_{1, \mathrm{i}}$, close to 0 imply in highly transitory earnings (Dichev \& Tang, 2008). The high persistence of earnings is considered a superior quality accounting feature (Kohlbeck \& Warfield, 2010).

The persistence of earnings is considered a measure of sustainability of earnings, in which persistent earnings is regarded as desirable because it is recurrent, making it more predictable, reinforcing its role in capital valuation, and helping financial analysts to provide valuable service to investors (Penman \& Zhang, 2002).

Persistence has also a direct connection with risk information, because greater persistence is associated with a more sustainable flow of earnings. Consequently, "if earnings are persistent, then investors need not be concerned about the extent to which the innovation in this period's earnings will continue, and this reduces one source of uncertainty" (Francis et al., 2004, p. 973).
The logic behind persistent earnings as measurement for quality is as follows: if firm A has a more persistent earnings flow than firm $B$, in perpetuity, then, (i) in firm A, current earnings is a summarized measure more useful for future performance; and (ii) annuitizing current earnings in firm A will generate smaller valuation errors than annuitizing current earnings in firm $\mathrm{B}$. Thus, higher persistent earnings is of superior quality when earnings are also relevant (Dechow et al., 2010).

\subsection{Predictability of earnings}

Predictable earnings are defined as the ability to predict earnings based on their past value (Francis et al., 2004; Yoon, 2007). The predictability of results is a widespread concern among financial executives, whose belief is that less predictable earnings (such as those that missed target earnings or volatile earnings) command the risk premium in the market (Graham, Harvey, \& Rajgopal, 2005).

Previous literature uses persistence to describe the ability of a given variable to predict another in a future period. Thus, high predictable earnings will be associated with a 
greater persistence of earnings (Wakil, 2011). The predictability of earnings is a function of the absolute average magnitude of annual (surprises) shock earnings, whereas the time-series persistence of earnings reflects the autocorrelation in earnings. Therefore, while persistence describes the timeseries relation between earning (surprise) shock in the current and future period, predictability reflects the variation of the earning (surprise) shock (Lipe, 1990).
The volatile or smaller earnings from those made by reference companies are evaluated as unpredictable and the unpredictability leads to low returns. The predictability of earnings makes it easier for investors to have an idea of how much of the earnings will be paid out (in dividend payments) versus how much will be reinvested (Graham et al., 2005).

Figure 3 presents the measurement model of the predictability of earnings used in this study.

\section{Earnings $s_{i, t}=\beta_{0, i}+\beta_{1, i}$ Earnings $_{i, t-1-1}+\varepsilon_{i, t-}$ \\ Earnings $\mathrm{s}_{i, \mathrm{t}}=$ net income before extraordinary items of the firm $i$ in the year $t$ divided by weighted mean number of shares in use during the year $t$. \\ Earnings, $\mathrm{i}_{,-1}=$ net income before extraor dinary items of the firm $i$ in the year $t$ divided by weighted mean number of shares in use during the year $t-1$.}

Figure 3 - Model to measure predictability of earnings

Source: Adapted from "Costs of equity and earnings attributes", by J. Francis, R. Lafond, P. M. Olsson and K. Schipper, 2004, The Accounting Review, 79, 967-1010.

The measure of predictability of earnings of Francis et al. (2004), also used by Yoon (2007) and Gaio (2010), considers the standard deviation of residues $\left(\varepsilon_{\mathrm{i}, \mathrm{t}}\right)$. Lower values of residues $\left(\varepsilon_{\mathrm{i}, \mathrm{t}}\right)$ imply in more predictable higher quality earnings. Higher values imply in less predictable results.

The predictability of earnings is an important measure as it deals with how well past earnings can explain current earnings. Hence, this measure strictly uses an accounting perspective, making it an ideal complement to value relevance. If past earnings are good estimates of current earnings then predictability is considered high. This characteristic is accounting-based, i.e., it considers the relations between accounting numbers (past earnings to current earnings) while ignoring information from outside the accounting regime, for example, the market perception regarding the reported earnings (Schiemann \& Guenther, 2013).

The predictability of earnings and relevance are theoretically linked (Nichols \& Wahlen, 2004). A more precise estimate of future earnings leads to a more precise forecast of future dividends, which in turn increases the accuracy of share price estimates as a representation of the present value of expected future dividends.

Empirically, Francis et al. (2004) find a small but considerable and positive correlation between these two measures. Bricker et al. (1995) demonstrate that the analysts associate high quality earnings with its predictability in the near term. The predictability "is defined in an economic sense in terms of a low level of earnings volatility, and in an accounting sense in terms of management discretion over the establishment and adjustment of certain conservative reserves, allowances, and of-balance-sheet assets," Bricker et al, (1995, p. 541).

Financial analysts understand earnings as being of high quality when a consistent repetition can be expected and with a high rate of predictability. Volatile earnings tend to be extreme earnings, which tend to revert faster to average (Freeman, Ohlson, \& Penman, 1982); this is an alternative explanation for volatile gains being 
less persistent. It is more likely of the volatility of earnings to include transitory items, and based on the assumption that transitory items are less persistent, the documented relation between the volatility and predictability of earnings can be an artifact of the effects of transitory items.

\subsection{Smoothing of earnings}

To ensure that financial statement users are not misled by inadequate financial statements, organizations are required to prepare financial statements based on Generally Accepted Accounting Principles. "However, GAAP cannot be overly restrictive, and needs to allow for flexible reporting to permit managers to convey relevant information concerning the operating environment of their businesses" (Habib, Hossain, \& Jiang, 2011, p. 257).

Many potential devices for smoothing have been discussed in the literature. Some involve the use of real (e.g., production and investment) decisions, while others center on the strategic choice of accounting techniques. Top management may have the ability to smooth income using both real and accounting techniques (Lambert, 1984).

The smoothing of earnings is a special case of management of results in which managers smooth intertemporal volatility of reported earnings to deliver a more stable flow of results (Biedleman, 1973). The management of results is characterized by intentional changes of the limits established by the accounting standard system (Martinez, 2001).
Nonetheless, Francis et al. (2004) observe that result smoothing derives from a view that managers use private information about future results to smooth the reported accounting numbers. Castro and Martinez (2009) argue that the practice of income smoothing impacts on the cost of third party capital and on the capital structure of firms. The results of Martinez and Castro (2011a) indicate that income smoothing has a positive effect on systematic risk, reducing it and favoring the achievement of positive abnormal returns. Additionally, Martinez and Castro (2011b) point out that income smoothing has a positive impact on the rating of firms.

"Smoothing is typically seen as a desirable attribute of earnings. Financial analysts and investors view volatility of earnings as undesirable and indicative of low quality of earnings" (Gaio, 2010, p. 699). The model proposed by Leuz, Nanda and Wysocki (2003), presented in Figure 4, aims to capture the degree in which executives practice smoothing of earnings, identifying how they reduce the variability of earnings, demonstrated by the change in the accounting components of earnings resulting from the adjustments in an accrual basis. Leuz et al. (2003) and Francis et al. (2004) consider the smoothing coefficient as the proportion between standard deviation of net income before extraordinary items divided by beginning total assets, to its standard deviation of cash flows from operations divided by beginning total assets.

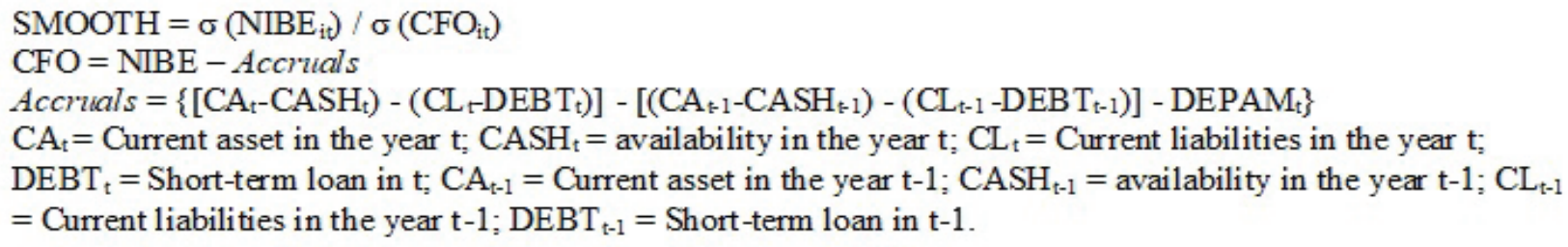

Figure 4 - Model of smoothing of earnings

Source: Adapted from "Earnings management and investor protection: an international comparison", by C. Leuz, D. Nanda and P. Wysocki, 2003, Journal of Financial Economics, 69, 505-527. 
Variable earnings are scaled by the operating cash flow from operational controls, which permit to control generically the differences in the variability of economic performance. Low values of this measure indicate that, ceteris paribus, insiders exercise accounting discretion to smooth reported earnings, Leuz et al. (2003). For the purposes of this study, it is assumed that smoothing is a desired attribute of earnings; therefore, less smoothing of earnings implies in lower quality of earnings (Gaio, 2010).

\section{Methodological trajectory}

The delineation of this study is related to the way in which the research problem was conceived, to the structure used for the experimentation, the data collection and the analysis (Kerlinger, 1980). Considering the characteristics of this study, the research can be outlined as descriptive, with documental data collection and quantitative approach.

It is possible to conceptualize this study as descriptive due to the use of standard techniques in the collection and analysis of the data, which allows us to establish relations between the explanatory variables and the dependent variable (Gil, 2006).
The documental collection (Martins \& Theóphilo, 2009) was based on accounting, financial, tax, and market data disclosed by the investigated firms and those produced by international organizations for the period between 2005 and 2012.

The population of the research was defined considering firms with open capital located in the twenty countries with the highest Gross Domestic Product (GDP) in 2012, according to the World Development Indicators (2014), produced by The World Bank. Based on information retrieved from the Thomson Datastream Index Service - TDIS (2014) database, it was decided to consider only countries that had more than 10 firms with the necessary variables to operationalize the theoretical models indicated in the literature review (Tables 1,2 and 3) resulting in a final sample composed by 1,406 firms from 12 countries. The countries of Saudi Arabia, South Korea, Spain, France, Italy, Mexico, Turkey and Russia were not represented in the final sample.

The distribution of firms by country is demonstrated in Table 1.

Table 1

\section{Distribution of firms by country}

\begin{tabular}{lcc|lcc}
\hline \multicolumn{1}{c}{ Country } & Firms & $\%$ & Country & Firms & $\%$ \\
\hline Germany & 35 & 2,49 & Netherlands & 16 & 1,14 \\
Australia & 47 & 3,34 & India & 72 & 5,12 \\
Brazil & 18 & 1,28 & Indonesia & 11 & 0,78 \\
Canada & 79 & 5,62 & Japan & 398 & 28,31 \\
China & 19 & 1,35 & United Kingdom & 124 & 8,82 \\
United Stated & 560 & 39,83 & Switzerland & 27 & 1,92 \\
\hline
\end{tabular}

Note: Adapted from “Screening \& Targeting” by Thomson One Banker, 2014

The quantification (Richardson, 1999) initially used multiple linear regression, with individual analysis per firm, to construct each of the attributes of the earnings. To define the weight of each vector using entropy (Zeleny, 1982), an aggregate quality ranking was constructed by using the multicriteria analysis of the Technique for Order Preference by Similarity to Ideal Solution 
- TOPSIS (Bulgurcu, 2012), presenting quality of accounting information, with individual scores between 0 and 1 .

As a characteristic of the business environment, economic, legal, tax and transparency aspects were considered. The tax burden of the countries considered a scale from 0 (high) to 10 (low), for the marginal tax rate, published by the Economic Freedom of the World - EFW (2013). The corruption perception index is a scale from 0 (highly corrupt countries) to 10 (highly transparent countries), published by Transparency International - TI (2012).

The natural logarithm of the gross domestic product per capita was used to measure the level of economic development, whereas for the level of financial development the capitalization in the stock market was used divided by the gross domestic product, both data published by The World Bank - WB (2014). The legal environment variable considered a scale ranging from 1 (weak) to 7 (robust), constructed from the linear mean of the indicators of application of laws for securities, protection of minority shareholders' interests, application of accounting and auditing standards, judicial independence, published by the World Economic Forum - WEF (2008-2013).
The level of internationalization corresponds to the proportion of sales and assets abroad in relation to total sales and total assets of the firms, adapted from the UNCTAD model (1995). After elaborating the ranking of accounting information quality of the firms and the construction of the explanatory variables, descriptive statistics, Pearson's correlation, t-tests of means and ANOVA test were elaborated.

\section{Presentation and analysis of results}

The main purpose of this section is to meet the specific objective of this study, which is to analyze how the characteristics of the business environment incites differences in the quality of accounting information in the international context.

\section{I Descriptive statistic of earnings attributes}

Table 2 presents the descriptive statistic of four individual variables of the quality of earnings measured according to the models presented in the Tables 1, 2 and 3.

Table 2

\section{Descriptive statistic}

\begin{tabular}{llllllllll}
\hline & Minimum & Maximum & Mean & Median & Std Dev & $10 \%$ & $25 \%$ & $75 \%$ & $90 \%$ \\
\hline AQ & 0,000 & 0,163 & 0,020 & 0,015 & 0,018 & 0,005 & 0,009 & 0,026 & 0,041 \\
PERS & $-1,859$ & 0,929 & $-0,321$ & $-0,291$ & 0,442 & $-0,904$ & $-0,607$ & $-0,003$ & 0,231 \\
PRED & 0,000 & 56,861 & 1,108 & 0,381 & 3,424 & 0,067 & 0,163 & 0,922 & 1,903 \\
SMOOTH & 0,036 & 1,836 & 0,733 & 0,743 & 0,336 & 0,297 & 0,475 & 0,963 & 1,155 \\
\hline
\end{tabular}

It can be observed in Table 2 that the quality of accruals (AQ) presents a mean (median) equal to 0.020 (0.015). Francis et al. (2004) found similar results in their sample of firms in the United States: mean of 0.026 and median of 0.019 .

The distribution of persistence (PERS) showed mean values (median) equal to 0.321 $(-0.291)$, while the predictability (PRED) indicated a mean (median) of 1.108 (0.381). Francis et al. (2004) found mean values higher than $-0.482(-0.520)$ to persistence and a lower mean for predictability (0.876), but the median of 0.636 was closer to the mean. On the other hand, the investigation by Gaio (2010) found lower values, with mean (median) persistence of $-0.227(-0.151)$ and predictability with values 
of $0.228(0.075)$, respectively. In relation to the fourth accounting variable, the smoothing (SMOOTH) indicated a mean (median) equal to 0.733 (0.743), respectively. In a comparative way, Francis et al. (2004) found $0.640(0.578)$ and the study of Gaio (2010) indicated a mean (median) of $0.765(0.680)$.

\subsection{Pearson correlation among earnings attributes}

In Table 3 are presented the Pearson correlations between four variables of the quality of earnings considered in this study.

Table 3

\section{Pearson correlation}

\begin{tabular}{lcccc}
\hline & AQ & PERS & PRED & SMOOTH \\
AQ & 1 & & & \\
PERS & $0,187^{* *}$ & 1 & & \\
PRED & $0,100^{* *}$ & $0,073^{* *}$ & 1 & 1 \\
SMOOTH & $0,401^{* *}$ & $0,144^{* *}$ & $0,136^{* *}$ & 1 \\
\hline
\end{tabular}

Note: ${ }^{* *}$ significant correlation at the level of $1 \%$.

The highest correlation value is between AQ and SMOOTH (0.401), followed by correlation between AQ and PERS (0.187), SMOOTH and PERS (0.144), SMOOTH and PREV (0.136), AQ and PRED (0.100) and SMOOTH and PERS (0.073). All correlations are significant at the $1 \%$ level. The results of Pearson's correlations are consistent with the study by Francis et al. (2004), who also found significant relationships among all accounting variables at the $1 \%$ level.

\subsection{Pearson correlation between explanatory variables}

Table 4 presents Pearson correlation between quantitative explanatory variables, indicating that all correlations presented significance at the $1 \%$ level. A value of 0.790 was found between the IPC and NDE variables, indicating a strong correlation. The other values vary between 0.082 and 0.430 , pointing to very low, low and moderate correlations (Dancey $\&$ Reidy, 2005).

Table 4

Pearson correlation between explanatory variables

\begin{tabular}{lcccccc}
\hline & CTB & ENVIRONMEN & CPI & NDE & NDF & D_INTER \\
\hline CTB & 1 & & & & & \\
ENVIORMEN & $-0,176 * *$ & 1 & & & & \\
CPI & $-0,340 * *$ & $0,305 * *$ & 1 & & & \\
LDF & $-0,082 * *$ & $0,256 * *$ & $0,790 * *$ & 1 & & \\
LDE & $0,391 * *$ & $0,365 * *$ & $0,335 * *$ & $0,430 * *$ & 1 & \\
D INTER & $-0,137 * *$ & $0,374 * *$ & $0,284 * *$ & $0,208 * *$ & $0,236 * *$ & 1 \\
\hline
\end{tabular}

Note: CTB = Country's tax burden (EFW); ENVIRONMENT = Country's legal environment (WEF); CPI = Corruption perception index (TI); LDE = Level of the country's economic development (WB); LDF = Level of development of the country's financial market (WB); D_INTER = Degree of Internationalization of firms (TDIS).

** The correlation is significant at the 0.01 level ( 2 extremities). 


\subsection{Aggregate measure of quality of accounting information}

Based on Pearson correlations found between variables of the attributes of earnings quality (Table 3), it can be evaluated that although there are significant relationships between quality measures based on accounting, they are of weak and moderate level (Dancey
\& Reidy, 2005), indicating that they capture diverse aspects of the earnings quality.

Therefore, a ranking of earnings quality per firm was elaborated, centered on the values of each of the four individual variables based on the attributes of accounting. Using the TOPSIS methodology, the vectors (weights) obtained through the entropy technique are those presented in Table 5.

Table 5

Vectors for the quality attributes of earnings based on accounting

\begin{tabular}{ll|ll}
\hline Variable & weight & Variable & weight \\
\hline AQ & 0,0480 & PRED & 0,0212 \\
PERS & 0,3183 & SMOOTH & 0,6125 \\
\hline
\end{tabular}

The ranking by country was elaborated based on the total of firms in each of the countries that host the firms of the investigated sample, according to Table 6.

Table 6

Descriptive statistics of the ranking of attributes based on accounting

\begin{tabular}{lcccccr}
\hline Country & Minimum & Maximum & Mean & Median & Std Dev. & \multicolumn{1}{l}{ Firms } \\
\hline Germany & 0,262 & 0,607 & 0,432 & 0,428 & 0,090 & 35 \\
Australia & 0,295 & 0,675 & 0,479 & 0,487 & 0,087 & 47 \\
Brazil & 0,289 & 0,493 & 0,402 & 0,460 & 0,055 & 18 \\
Canada & 0,262 & 0,621 & 0,447 & 0,447 & 0,082 & 79 \\
China & 0,276 & 0,520 & 0,406 & 0,406 & 0,068 & 19 \\
United States & 0,237 & 0,735 & 0,466 & 0,468 & 0,094 & 560 \\
Netherlands & 0,372 & 0,646 & 0,479 & 0,472 & 0,077 & 16 \\
India & 0,289 & 0,731 & 0,416 & 0,400 & 0,083 & 72 \\
Indonesia & 0,275 & 0,675 & 0,442 & 0,407 & 0,119 & 11 \\
Japan & 0,233 & 0,731 & 0,417 & 0,409 & 0,093 & 398 \\
United Kingdom & 0,247 & 0,696 & 0,453 & 0,443 & 0,095 & 124 \\
Switzerland & 0,298 & 0,667 & 0,463 & 0,447 & 0,107 & 27 \\
\hline Total & & & & & 0,088 & 1.406 \\
Mean & 0,278 & 0,650 & 0,442 & 0,439 & 0,058 \\
\hline
\end{tabular}

Based on the chosen procedure, each firm received a score that varies between 0 (zero) and 1 (one) in the ranking of quality of accounting information (QAI) elaborated with accountingbased attributes. A value closer to 1 in the ranking implies in a higher level of earnings quality and values closer to 0 indicate lower earnings quality. The results presented in Table 6 indicate that the means are close to the medians, which suggests that there are no problems with outliers. The highest variation is identified in Brazilian $(12.6 \%)$ and Indonesian firms (8.6\%); the other countries presented a variation of less than $4 \%$. It can be observed that firms from Canada and China presented equal values for mean and median. The firms with the lowest score are 
found in Japan (0.233) and the highest score in the United States (0.735). The lowest mean was found among Brazilian firms, whereas the highest mean was found among firms in Australia and the Netherlands, with 0.479 . The lowest median can be seen in firms in India and the highest median was found among Australian firms.

\subsection{Tests of means}

Table 7 presents Student's $t$-test calculation from independent samples in order to verify if there are differences in the means of the ranking of quality of accounting information between the groups.

Table 7

$t$ Test of means

\begin{tabular}{|c|c|c|c|c|c|c|c|}
\hline Panel A & GROUP & $\mathrm{N}$ & Mean & Panel E & GROUP & $\mathrm{N}$ & Mean \\
\hline \multirow[t]{2}{*}{ CTB } & 1 & 699 & 0,433 & \multirow[t]{2}{*}{ LFD } & 1 & 616 & 0,424 \\
\hline & 2 & 707 & 0,457 & & 2 & 790 & 0,462 \\
\hline Panel B & & $\mathrm{N}$ & Mean & \multirow{3}{*}{$\begin{array}{l}\text { Panel F } \\
\text { ORIGIN }\end{array}$} & & $\mathrm{N}$ & Mean \\
\hline \multirow[t]{2}{*}{ LEGAL } & 1 & 446 & 0,417 & & 1 & 882 & 0,459 \\
\hline & 2 & 960 & 0,459 & & 2 & 524 & 0,422 \\
\hline Panel C & & $\mathrm{N}$ & Mean & Panel G & & $\mathrm{N}$ & Mean \\
\hline \multirow[t]{2}{*}{ CPI } & 1 & 661 & 0,458 & \multirow[t]{2}{*}{ D_INTER } & 1 & 703 & 0,423 \\
\hline & 2 & 745 & 0,433 & & 2 & 703 & 0,468 \\
\hline Panel D & & $\mathrm{N}$ & Mean & & & & \\
\hline \multirow[t]{2}{*}{ LED } & 1 & 677 & 0,424 & & & & \\
\hline & 2 & 729 & 0,465 & & & & \\
\hline
\end{tabular}

In panels $A, B, C, D, E, G$, the median of each variable was used as the criterion for dividing the groups of firms, in which group 1 contains the firms with scores below the median and group 2 represents the firms with score equal to or greater than the median. In panel $\mathrm{F}$, in group 1 , are the firms located in countries of common law origin and in group 2 are the firms located in code law countries.

The results of Table 7 indicate that firms located in countries with lower tax burden, stronger legal environment, higher economic development index, higher financial development index, legal origin of common law, and with higher degree of internationalization presented higher means in the aggregate ranking of QAI, as expected.

Table 8 presents Levene's test to verify the populational equal variance between two groups and $\mathrm{t}$-Test for equity of means. When Levene's test is significant $(<0.05)$, it is accepted that the variances are statistically different, using the data of the not assumed equal variances. However, if Levene's test does not demonstrate significance (> 0.05 ), it must be accepted that the variances are homogeneous, using the equal variance assumed data (Favero, Belfiore, Silva, \& Chan, 2009).

The results of Table 8 indicate that Levene's test presented higher significance at 0.05 in all groups of tests, allowing us to conclude that variances are homogeneous (equal variance assumed). The results of $\mathrm{t}$-Test for equal means pointed that $\mathrm{p}$-value is equal to 0.000 in all the samples, indicating that the population mean is different (Fávero et al., 2009). 
Table 8

Test of independent samples

\begin{tabular}{|c|c|c|c|c|c|c|}
\hline \multirow{2}{*}{\multicolumn{2}{|c|}{ Variables }} & \multicolumn{2}{|c|}{$\begin{array}{c}\text { Levene's test for equal } \\
\text { variance }\end{array}$} & \multicolumn{3}{|c|}{$t$-test for equality of the means } \\
\hline & & $\mathrm{F}$ & Significance & $t$ & DF & Sig.* \\
\hline \multirow{2}{*}{$\begin{array}{l}\text { Panel A } \\
\text { CTB }\end{array}$} & Equal variance assumed & \multirow[t]{2}{*}{0,106} & \multirow[t]{2}{*}{0,744} & $-4,848$ & 1404 & 0,000 \\
\hline & Equal variance not assumed & & & $-4,849$ & 1404 & 0,000 \\
\hline \multirow{2}{*}{$\begin{array}{l}\text { Panel B } \\
\text { LEGAL }\end{array}$} & Equal variance assumed & \multirow[t]{2}{*}{0,786} & \multirow[t]{2}{*}{0,375} & $-7,927$ & 1404 & 0,000 \\
\hline & Equal variance not assumed & & & $-7,980$ & 882 & 0,000 \\
\hline \multirow{2}{*}{$\begin{array}{l}\text { Panel C } \\
\text { CPI }\end{array}$} & Equal variance assumed & \multirow[t]{2}{*}{0,053} & \multirow[t]{2}{*}{0,818} & 5,009 & 1404 & 0,000 \\
\hline & Equal variance not assumed & & & 5,007 & 1382 & 0,000 \\
\hline \multirow{2}{*}{$\begin{array}{l}\text { Panel D } \\
\text { LED }\end{array}$} & Equal variance assumed & \multirow[t]{2}{*}{0,137} & \multirow[t]{2}{*}{0,711} & $-8,373$ & 1404 & 0,000 \\
\hline & Equal variance not assumed & & & $-8,374$ & 1397 & 0,000 \\
\hline \multirow{2}{*}{$\begin{array}{l}\text { Panel E } \\
\text { LFD }\end{array}$} & Equal variance assumed & \multirow[t]{2}{*}{0,600} & \multirow[t]{2}{*}{0,439} & $-7,708$ & 1404 & 0,000 \\
\hline & Equal variance not assumed & & & $-7,729$ & 1335 & 0,000 \\
\hline \multirow{2}{*}{$\begin{array}{l}\text { Panel F } \\
\text { ORIGIN }\end{array}$} & Equal variance assumed & \multirow[t]{2}{*}{0,169} & \multirow[t]{2}{*}{0,681} & $-7,276$ & 1404 & 0,000 \\
\hline & Equal variance not assumed & & & $-7,280$ & 1100 & 0,000 \\
\hline \multirow{2}{*}{$\begin{array}{l}\text { Panel G } \\
\text { D_INTER }\end{array}$} & Equal variance assumed & \multirow[t]{2}{*}{0,395} & \multirow[t]{2}{*}{0,530} & $-9,271$ & 1404 & 0,000 \\
\hline & Equal variance not assumed & & & $-9,271$ & 1403 & 0,000 \\
\hline
\end{tabular}

Note: ${ }^{*} 2$ extremities.

From the results obtained in Tables 7 and 8 , it is possible to verify that characteristics of host countries such as tax burden, legal environment, level of economic and financial development, legal origin, and level of transparency lead to significant differences between the firms in the ranking of the quality of accounting information reported. In addition, it is observed that the highest degree of internationalization of the firms is also a significant factor to be considered to explain the position in the ranking of QAI.

\subsection{ANOVA Test}

Regarding the accounting standards, the firms were separated in four groups: (1) firms that used IFRS throughout the period;
(2) firms that used US GAAP throughout the period; (3) firms with partial use of IFRS over the period investigated; (4) firms that only used their national accounting standards. To test the existence of differences in the QAI means between the firms and their respective groups, it was used the Analysis of Variance test (ANOVA). Group 1 is composed of 222 firms from Australia, Germany, United Kingdom and Netherlands. In group 2 are 560 firms located in the United States. In group 3 there are 514 firms based in Brazil, Canada, China, and Japan. Finally, in group 4 there are 110 firms located in Switzerland, Indonesia and India.

Table 9 presents the test for homogeneity of variances.

Table 9

\section{Homogeneity of variances test}

\begin{tabular}{c|c|c|c}
\hline Levene Statistic & Degrees of freedom 1 & Degrees of freedom 2 & Significance \\
\hline 0,438 & 3 & 1402 & 0,726 \\
\hline
\end{tabular}


Considering that the significance value is $>0.05$, the equality of variances between the four groups is accepted (Fávero et al, 2009). Table 10 presents the ANOVA test to verify the existence of differences in the QAI among the different accounting standards used.

Table 10

Test Anova

\begin{tabular}{l|l|l|l|l|l}
\hline & Soma dos Quadrados & $\begin{array}{c}\text { Graus de } \\
\text { liberdade }\end{array}$ & $\begin{array}{c}\text { Quadrado } \\
\text { Médio }\end{array}$ & F & Significância \\
\hline Entre Grupos & 0,607 & 3 & 0,202 & 23,827 & 0,000 \\
Nos grupos & 11,912 & 1402 & 0,008 & & \\
Total & 12,519 & 1405 & & \\
\hline
\end{tabular}

In the ANOVA test, low significance values indicate differences between the means of the groups. The significance was 0.000 ( $\mathrm{p}$-value $<0.05$ ), indicating that there is at least one difference between the analyzed groups (Fávero et al., 2009). Thus, the null hypothesis is rejected (the variability BETWEEN the groups was sufficiently large in relation to the variability WITHIN the groups). Therefore, the means of QAI are not equal between the four groups of accounting standards used in the sample and in the periods investigated.

In order to identify the group where the differences were, a comparison was made between the pairs, comparing each group with each one of the others. Then, multiple comparison tests of means were used (Post Hoc) that compare all the groups two by two, using Tukey test. The Post Hoc test (not evidenced) indicated that there are significant differences in the QAI between (a) the group 1 (IFRS) and the group 3 (partial IFRS); (b) the group 2 (US GAAP) and the groups 3 (partial IFRS) and 4 (other national standards); (c) the group 3 (partial IFRS) and the groups 1 (IFRS) and 2 (partial IFRS); (d) the group 4 (other national standards) and the group 2 (US GAAP).

Table 11 presents Tukey HSD Test to verify the existence of significant difference (honestly significant difference - HSD), among other homogeneous subgroups.

Table 11

\section{Tukey HSD}

\begin{tabular}{l|c|c|c}
\hline \multirow{2}{*}{ Accounting Standard - AS } & \multirow{2}{*}{$\mathrm{N}$} & \multicolumn{2}{|c}{ Subgroup to alfa $=0,05$} \\
\cline { 3 - 4 } & & 1 & 2 \\
\hline 3-Partial IFRS & 514 & 0,421 & \\
4-National standards & 110 & 0,430 & 0,457 \\
1-IFRS & 222 & & 0,466 \\
2-US GAAP & 560 & & 0,687 \\
\hline Significance & & 0,695 & \\
\hline
\end{tabular}

The results of Table 11 indicate that groups 3 and 4 form a homogeneous subgroup, while groups 1 and 2 form another homogeneous group. Thus, the firms that adopted IFRS accounting standards in a partial way and those that used only their national standards presented 
similar levels of QAI. Differently, firms that adopted US GAAP and IFRS throughout the period surveyed, presented similar performance among themselves and superior in relation to the other groups of firms. In these two subgroups, the differences between them are not significant.

\subsection{Main results}

The results corroborate the theoretical assumptions that the IFRS standard is oriented to improve the quality of accounting information, as in the findings of Barth et al. (2008) and Naranjo, Saavedra and Verdi (2013). In addition, they confirm the relevance of the US GAAP standard for the generation of high quality accounting information, such as in the results of Leuz (2003) and Barth et al. (2012).

Based on the findings, the relevance of the countries' economic development in the explanation of the accounting numbers reported is confirmed. (Isidro \& Raonic, 2012). The countries' economic might makes viable the existence and maintenance of more independent and more effective Judicial Courts that defend the rights of minority shareholders and creditors.

The results for the level of development in the countries' financial market confirmed that environments with more active capital markets require a greater demand for information by the financing sources and the occurrence of less involvement in results management, in alignment with the findings of Leuz et al. (2003) and Burgstahler et al. (2006).

The results for legal environment confirm the assumption that countries whose regulatory environments have stronger institutions provide higher levels of reporting quality (Bushman \& Piotroski, 2006). Regarding the tax burden, as Ball et al. (2000) proposed, the tax burden can generate greater conservatism in financial reports, with higher quality accounting numbers, since conservatism is a desired attribute.

In countries of common law, firms are often funded by investors and present a proper structure of corporate governance (Ball et al.,
2000). This scenario favors the demand for higher quality accounting information, given the high demand of investors for monitoring organizational performance and the return on their investments, which justifies the results found (Mazzioni, 2015).

The international expansion of business increases the complexity of information processing for analysts, investors and auditors. International diversification creates greater informational need and creates greater incentives for firms to provide high quality information (Rusanescu, 2013).

The results reinforce the multidimensionality of the factors that interfere in the quality of accounting information reported in the international context, in which several characteristics of the environment play as determinants of accounting numbers evidenced (Mazzioni, 2015).

\section{C o n c 1 us i o n s recommendations}

This study analyzed how the characteristics of the business environment incites differences in the quality of accounting information in the international context, based on an aggregated ranking of quality of accounting information constituted by four earnings attributes of accounting-basis. Initially, Pearson's correlation indicated that four quality attributes of earnings used in this study presented significant correlations at the level of $1 \%$, in accordance with the study of Francis et al. (2004). Based on each individual attribute of the investigated firms, a ranking of aggregate quality of accounting information was generated using TOPSIS multicriteria analysis and entropy technique.

It was verified that in general the Brazilian firms presented the lowest scores in the accounting quality ranking. On the other hand, Australian and Dutch firms demonstrated as generally having the highest accounting quality. Swiss firms presented a greater individual discrepancy in relation to the mean of the group of firms of that country. However, Brazilian firms indicated 
a greater homogeneity in relation to the country as a whole.

The tests of means, considering the separation in groups from the median of each variable, indicated that the firms located in countries with lower tax burden, stronger legal environment, higher level of economic development, higher index of financial development, firms of common law legal origin and more internationalized presented higher means in the aggregate ranking of QAI.

Regarding the accounting standards used by the sample, a homogeneous subgroup between IFRS and US GAAP was observed and a homogeneous subgroup between the partial use of IFRS and the use of national standards. The first subgroup presented superior results in the ranking aggregate of accounting information quality, reinforcing the knowledge that good accounting standards produce higher quality accounting numbers (Soderstrom \& Sun, 2007; Iatridis, 2010; Houqe et al., 2012).

The results confirmed that the quality of accounting information reported is a result of institutional factors of the operating environment and of business characteristics, such as the intensity of internationalization (Isidro \& Raonic, 2012).

This study allows us to conclude that the degree of internationalization is an important explanatory determinant of the quality of accounting information, since such activities subject the firms to market forces that demand higher levels of information regarding the domestic environment. The degree of internationalization of firms, together with the characteristics of the environment (economic, legal, tax), influences positively the quality of accounting information.

It is recommended for future studies to expand the number of countries in order to diversify the institutional characteristics of the business environment and to consider business incentives that influence the reported accounting numbers. Another approach could be to consider the analysis of attributes of market-based earnings, such as relevance, timeliness and conservatism, since these attributes may be related to different incentives other than the accounting-basis considered in this study.

\section{References}

Ball, R., Kothari, S. P., \& Robin, A. (2000). The effect of international institutional factors on properties of accounting earnings. Journal of Accounting and Economics, 29(1), 1-51. doi: 10.1016/S0165-4101(00)00012-4

Ball, R., \& Shivakumar, L. (2005). Earnings quality in U.K. Private firms: comparative loss recognition timeliness. Journal of Accounting and Economics, 39(1), 83-128. doi: 10.1016/j. jacceco.2004.04.001

Barth, M. E., Landsman, W. R., \& Lang, M. H. (2008). International Accounting Standards and accounting quality. Journal of Accounting Research, 46(3), 467-498. doi: 10.1111/j.1475679X.2008.00287.x

Barth, M. E., Landsman, W. R., Lang, M., \& Williams, C. (2012). Are IFRS-based and US GAAP-based accounting amounts comparable? Journal of Accounting and Economics, 54, 68-93. doi: 10.1016/j.jacceco.2012.03.001

Biedleman, C. (1973). Income smoothing: The role of management. The Accounting Review, 48(4), 653-667.

Bradshaw, M., Bushee, B., \& Miller, G. (2004). Accounting choice, home bias, and U.S. investment in non-U.S. firms. Journal of Accounting Research, 42(5), 795-838. doi: 10.1111/j.1475-679x.2004.00157.x

Bricker, R., Previts, G., Robinson, T., \& Young, S. (1995). Financial analyst assessment of company earnings quality. Journal of Accounting, Auditing and Finance, 10(3), 541-554. doi: 10.1177/0148558X9501000307

Bulgurcu, B. K. (2012). Application of TOPSIS Technique for financial performance evaluation 
of technology firms in Istanbul Stock Exchange Market. Procedia - Social and Behavioral Sciences, 62(24), 1033-1040. doi: 10.1016/j. sbspro.2012.09.176

Burgstahler, D., Hail, L., \& Leuz, C. (2006). The importance of reporting incentives: earnings management in European private and public firms. The Accounting Review, 81(5), 983-1016. doi: 10.2308/accr.2006.81.5.983

Bushman, R. M., \& Piotroski, J. D. (2006). Financial reporting incentives for conservative accounting: The influence of legal and political institutions. Journal of Accounting and Economics, 42(1-2), 107-148. doi: 10.1016/j. jacceco.2005.10.005

Castro, M. A. R., Martinez, A. L. (2009). Income smoothing, cost of debt capital and capital structure in Brazil. Revista de Administração Mackenzie, 10(6), 25-46. doi: 10.1590/s167869712009000600004

Chen, H., Tang, Q., Jiang, Y., \& Lin, Z. (2010). The role of accounting standards: evidence from the European Union. Journal of International Financial Management \& Accounting, 21(3), 1-57. doi: 10.1111/j.1467-646x.2010.01041.x

Dancey, C., \& Reidy, J. (2006). Estatística sem matemática para psicologia: usando SPSS para Windows. Porto Alegre, Artmed.

Daske, H., Hail, L., Leuz, C., \& Verdi, R. (2008). Mandatory IFRS adoption around the world: early evidence on the economic consequences. Journal of Accounting Research, 46(5), 1085-1142. doi: 10.1111/j.1475-679X.2008.00306.x

Dechow, P. (1994). Accounting earnings and cash flows as measures of firm performance: the role of accounting accruals. Journal of Accounting and Economics, 18(1), 3-42. doi: 10.1016/01654101(94)90016-7

Dechow, P., \& Dichev, I. (2002). The quality of accruals and earnings: the role of accrual estimation errors. The Accounting Review, 77(4), 35-59.

Dechow, P., Ge, W., \& Schrand, C. (2010). Understanding earnings quality: a review of the proxies, their determinants and their consequences. Journal of Accounting and Economics, 50(2-3), 344-401. doi: 10.1016/j.jacceco.2010.09.001

Dichev, I. D., \& Tang, V. W. (2008). Matching and the changing properties of accounting earnings over the last 40 years. The Accounting Review, 83(6), 1425-1460. doi: 10.2308/ accr.2008.83.6.1425

Economic Freedom of the World. 2013 Dataset. Fraser Institute. Available at: http://www. freetheworld.com/release.html. Accessed on: Feb 20, 2014.

Fávero, L. P., Belfiore, P., Silva, F. F., \& Chan, B. L. (2009). Análise de dados: modelagem multivariada para tomada de decisóes. Rio de Janeiro: Elsevier.

Francis, J., Lafond, R., Olsson, P. M., \& Schipper, K. (2004). Costs of equity and earnings attributes. The Accounting Review, 79(4), 967-1010. doi: 10.2308/accr.2004.79.4.967

Freeman, R., Ohlson, J., \& Penman, S. (1982). Book rate of return and prediction of earnings changes: an empirical investigation. Journal of Accounting Research, 20(2), 639-653. doi: $10.2307 / 2490890$

Gaio, C. (2010). The relative importance of firm and country characteristics for earnings quality around the world. European Accounting Review, 19(4), 693-738. doi: 10.1080/09638180903384643

Gil, A. C. (2006). Métodos e técnicas de pesquisa social. 5. ed. São Paulo: Atlas.

Goulart, A. M. C. (2007). Gerenciamento de resultados contábeis em instituiçôes financeiras no Brasil. Tese de doutorado, Universidade de São Paulo, São Paulo, SP, Brasil. 
Graham, J. R., Harvey, C. R., \& Rajgopal, S. (2005). The economic implications of corporate financial reporting. Journal of Accounting and Economics, 4O(1-2), 3-73. doi: 10.3386/w10550

Habib, A., Hossain, M., \& Jiang, H. (2011). Environmental uncertainty and the market pricing of earnings smoothness. Advances in Accounting, Incorporating Advances in International Accounting, 27(2), 256-265. doi: 10.1016/j. adiac.2011.04.003

Hribar, P., Kravet, T., \& Wilson, R. (2014). A new measure of accounting quality. Review of Accounting Studies, 19(1), 506-538. doi: 10.1007/s1 1142-013-9253-8

Houqe, M. N. H., Van Zijl, T., Dunstan, K., \& Karim, A. K. M. W. (2012). The effect of IFRS adoption and investor protection on earnings quality around the world. The International Journal of Accounting, 47(3), 333-355. doi: 10.1016/j.intacc.2012.07.003

Iatridis, G. (2010). International Financial Reporting Standards and the quality of financial statement information. International Review of Financial Analysis, 19(3), 193-204. doi: 10.1016/j.irfa.2010.02.004

Isidro, H., \& Raonic, I. (2012). Firm incentives, institutional complexity and the quality of "harmonized" accounting numbers. The International Journal of Accounting, 47(4), 407436. doi: 10.1016/j.intacc.2012.10.007

Kerlinger, F. N. (1980). Metodologia da pesquisa em ciências sociais: um tratamento conceitual. São Paulo: EPU.

Kohlbeck, M., Warfield, T. (2010). Accounting standard attributes and accounting quality: discussion and analysis. Research in Accounting Regulation, 22(2), 59-70. doi: 10.1016/j. racreg.2010.07.001

Lambert, R. A. (1984). Income smoothing as rational equilibrium behavior. The Accounting Review, v. 59(4), 604-618.
La Porta, R., Lopez-De-Silanes, F., Shleifer, A., \& Vishny, R. W. (1998). Law and finance. Journal of Political Economy, 106(6), 1113-1155.

La Porta, R., Lopez-De-Silanes, F., \& Shleifer, A. (2008). The economic consequences of legal origins. Journal of Economic Literature, 46(2), 285-332. doi: 10.1257/jel.46.2.285

Land, J., \& Lang, M. H. (2002). Empirical evidence on the evolution of international earnings. The Accounting Review, 77(Supplement), 115-133.

Leuz, C. (2003). IAS versus U.S. GAAP: Information asymmetry-based evidence from Germany's new market. Journal of Accounting Research, 41(3), 445-472. doi: 10.1111/1475679x.00112

Leuz, C., Nanda; D., \& Wysocki, P. (2003). Earnings management and investor protection: an international comparison. Journal of Financial Economics, 69(3), 505-27. doi: 10.1016/S0304405X(03)00121-1

Lipe, R. (1990). The relation between stock returns and accounting earnings given alternative information. The Accounting Review, 65(1), 49-71.

Martinez, A. L. (2001). Gerenciamento dos resultados contábeis: estudo empírico das companhias abertas brasileiras. Tese de doutorado, Universidade de São Paulo, São Paulo, SP, Brasil.

Martinez, A. L. (2008). Detectando earnings management no Brasil: estimando os accruals discricionários. Revista Contabilidade \& Finanças, 19(46), 7-17. doi: 10.1590/s151970772008000100002

Martinez, A. L., \& Castro, M. A. R. (2011a). The smoothing hypothesis, stock returns and risk in Brazil. Brazilian Administration Review, 8(1), 1-20. doi: 10.1590/s1807-76922011000100002

Martinez, A. L., Castro, M. A. R. (2011b). Bond ratings and income smoothing in Brazil. Latin 
American Business Review, 12(2), 59-81. doi: 10.1080/10978526.2011.592793

Martins, G. A.; Theóphilo, C. R. (2009). Metodologia da investigação científica para ciências sociais aplicadas (2a. ed.). São Paulo, Atlas.

Mazzioni, S. (2015). Influência do grau de internacionalização das empresas na relação entre as normas reguladoras e os incentivos empresariais com a qualidade das informaçôes contábeis. Tese de doutorado, Universidade Regional de Blumenau, Blumenau, SC, Brasil.

Myers, J. N., Myers, L. A., \& Skinner, D. J. (2006). Earnings momentum and earnings management. 2006. Retrieved April 14, 2014 , from http://ssrn.com/abstract $=741244$.

McNichols, M. (2002). Discussion of the quality of accruals and earnings: the role of accrual estimation errors. The Accounting Review, 77 (Supplement), 61-69.

Naranjo, P. L.; Saavedra, D.; Verdi, R. S. (2015). Financial reporting regulation and financing decisions. Retrieved on Jun 3, 2015, from http:// ssrn.com/abstract $=2147838$.

Nichols, D. C., Wahlen, J. M. (2004). How do earnings numbers relate to stock returns? A review of classic accounting research with updated evidence. Accounting Horizons, 18(4), 263-286. doi: 10.2308/acch.2004.18.4.263

Penman, S. H., \& Zhang, X-J. (2002). Accounting conservatism, the quality of earnings and stock returns. The Accounting Review, 77(2), 237-264.

Richardson, R. J. (1999). Pesquisa social: métodos e técnicas (2a ed.). São Paulo: Atlas.

Rusanescu, S. (2013). La internacionalización de la empresa y la calidad de la información contable: Evidencia para España. Madrid: Instituto de Contabilidad y Auditoría de Cuentas.
Schiemann, F., Guenther, T. (2013). Earnings predictability, value relevance, and employee expenses. The International Journal of Accounting, 48(2), 149-172. doi: 10.1016/j. intacc.2013.04.001

Soderstrom, N. S., \& Sun, K. J. (2007). IFRS adoption and accounting quality: a review. The European Accounting Review, 16(4), 675-702. doi: $10.1080 / 09638180701706732$

The World Bank. (2014). Data. World development indicators. Retrieved April 14, 2014, from http://data.worldbank.org/indicator.

Thomson One Banker. (2014). Screening \& Targeting. Retrieved April 14, 2014, from http:// banker.thomsonib.com/ta/TAdashboard.aspx.

Transparency International. (2012). Corruption perceptions index. Retrieved April 14, 2014, from http://www.transparency.org.

United Nations Conference on Trade and Development - UNCTAD. (1995). World Investment Report 1995. Transnational corporations and competitiveness. Geneva: United Nations.

Yoon, S. (2007). Accounting quality and international accounting convergence. Dissertation (Doctor of Philosophy) - Oklahoma State University, Oklahoma.

Wakil, G. (2011). Conservatism, earnings persistence, and the accruals anomaly. Dissertation (Doctor of Philosophy) - Kent State University Graduate School of Management.

World Economic Forum. (2013). The Financial Development Report. Retrieved April 14, 2014 , from http://www.weforum.org/issues/financialdevelopment.

Zeleny, M. (1982). Multiple criteria decision making. New York: McGraw-Hill. 


\section{Notes}

1 A preliminary version of this article "Aspects of the Quality of Accounting Information in the International Context" at the $9^{\text {th }}$ Ibero-American Congress of Accounting and Management, held from September 30 to October 2, 2015 at the Universidade Federal de Santa Catarina.

2 Article derived from the doctoral thesis: "Influence of the degree of internationalization of companies on the relationship between regulatory norms and business incentives with the quality of accounting information" defended by Sady Mazzioni in 2015, Post-Graduate Program in Accounting Sciences of the Universidade Regional de Blumenau, Blumenau.

\section{About the authors:}

1. Sady Mazzioni, PhD in Accounting and Business Administration, Universidade Regional de Blumenau (FURB), Brazil. E-mail: sady@unochapeco.edu.br

ORCID

(iD) 0000-0002-8976-6699

2. Roberto Carlos Klann, PhD in Accounting and Business Administration, Universidade Regional de Blumenau (FURB), Brazil. E-mail: rklann@furb.br

ORCID

(iD 0000-0002-3498-0938

\section{Contribution of each author:}

\begin{tabular}{lcc}
\hline Contribution & Sady Mazzioni & Roberto Carlos Klann \\
\hline 1. Definition of research problem & $\sqrt{ }$ & $\sqrt{ }$ \\
2. Development of hypotheses or research questions ( empirical studies) & - & - \\
3. Development of theoretical propositions (theoretical Work) & - & $\sqrt{ }$ \\
4. Theoretical foundation/ Literature review & $\sqrt{ }$ \\
5. Definition of methodological procedures & $\sqrt{ }$ \\
6. Data collection & $\sqrt{ }$ \\
7. Statistical analysis & $\sqrt{ }$ \\
8. Analysis and interpretation of data & $\sqrt{ }$ \\
9. Critical revision of the manuscript & $\sqrt{ }$ \\
10. Manuscript Writing & $\sqrt{ }$ & $\sqrt{ }$ \\
\hline
\end{tabular}

